\title{
Underdeveloping the Disadvantaged: The Dilemma of Globalization on Women in a Developing Country
}

\author{
Dr. Patricia A. Taiwo \\ Department of Sociology, Faculty of the Social Sciences, University of Ibadan
}

\begin{abstract}
Globalization in its meanings and focus is a phenomenon with anticipated promises and possibilities whose impact can be highly felt and appreciated in the face of gender equality. Achieving such may remain an insurmountable brick wall in a developing country like Nigeria. This is especially so when we consider the disadvantage women experience due to the patriarchal nature of the Nigerian system, high level of poverty, increased marginalization and segregation, invisibility and experienced limitations and difficulty in participating and succeeding in power relations, participation in unpaid and less paid jobs (coupled with the devaluation of the Nigerian currency), inability to move and grow in their career pursuit at the same pace with men due to reproductive health issues, socialization of children, women's "seemingly" unappreciated loss of identity to the men (through marriage) and the general orientation that women are meant to be at the "background". Conceptualizing globalization from Anderson's view point and hinged on the theory of feminism, this paper addresses the effect of these disadvantages on women's lives and opportunities in the Nigerian society at a critical point as this when the country is undergoing economic recession. It concludes that women are more likely to experience underdevelopment despite the possibilities and promises of globalization. It recommends a holistic approach which will involve revisiting some policies, passing some bills, educating, enlightening, re-orientating the necessary stake holders as well as empowering women and re-enforcing gender mainstreaming in all facets of the society in order to reduce the effect of these experiences on their development in the Nigerian society.
\end{abstract}

DOI: $10.7176 / \mathrm{JESD} / 10-8-16$

Publication date: April $30^{\text {th }} 2019$

\section{Introduction}

The world in this twenty-first century is one with so many dialectics and complexities in the face of development. However, one of the complexities that is full of contradictions in contemporary societies, is the phenomenon of globalization itself (Haug, 2007; The Royal Institute of International Affairs, 2015). Right from the 18th century, many societies and socio-economic political units have increasingly become interdependent and reliant on oneanother through terms of trade, culture and political activities. This is especially so because, just like every human being, no one society can live in isolation. Many scholars have alluded to the fact that the world is rapidly becoming a global village (Akanle, 2011, Akanle and Taiwo, 2013). This phenomenon is brought about by the unprecedented advancement in telecommunications, transport technology, information and international flow of capital (Olutayo and Akanle, 2012). Therefore, various social, cultural, economic or political issues affecting a nation will almost immediately have ripple effects on other societies' social structures and institutions down to the interpersonal relationships and interactions that take place within them. A case in point is the complex consequence the Great Recession (between 2008 and 2009) had on the nations of the world - developed and developing alike (Verick and Islam, 2010; Berg, 2011).

Globalization which involves a linkage, shrinking and reduction of virtual and physical spaces of world societies have no doubt brought several benefits for both the common man and the large institutions whether in a developed or developing society. However, with this seeming convergence, simultaneously, there is increasing dissimilarities and heterogeneity of individuals, sub-cultures, spatial areas, nations and socio-economic entities. As two sides of a coin that usually move together, these divergent consequences of globalization are reflective of the inequalities that are inherent in the World Capitalist System (Shittu and Taiwo, 2016). Developing countries such as Nigeria are constantly experiencing a disjuncture between their aspirations towards achieving sustainable development and the low standard of living of their citizenry despite the promises.

A searchlight into these developing countries such as Nigeria will further reveal that the inequality that arise from international trade aided by globalization has more adversely affected the female gender than the male (Bacchus, 2005). Just as the developed countries and multi-national corporations, through their economic activities, further exploit and impoverish the periphery nations, it is in the latter's patriarchal societies' interest to continuously subjugate the female gender. This subjugation is sharply defined by the unpaid labour women are subjected to in homes, the undervalued labour they render for underpaid jobs and the political subjugation and exclusion they often experience particularly in the Nigerian society. Of the two basic genders, women are now seen as being the more disadvantaged group in terms of resource accessibility and allocation (Erinosho 2005; Oludayo and Aderinto, 2011; Sabarwal, Sinha and Buvinic, 2009). This is worsened to the extent that in Africa and especially Nigeria, we can now speak of an empirically justified notion of the feminization of poverty (United 
Nations, 2004; BRIDGE, 2001). In fact, almost all social problems experienced in Nigeria today (which most times are consequential interactions of global and local phenomenon), usually manifest their worst effects on women and children (Erinosho, 2005; Taiwo and Owumi, 2014; Olutayo, 2005)

In the light of the above, this paper will take a look at the disadvantaged position of women in Nigeria - a developing country - vis-à-vis the issues of globalization and feminism; the consequences of globalization on the female gender; and the effects these consequences have for women's personal and socio-economic development. To this end, the paper will recommend some policy actions that can be taken to re-channel the disadvantages of globalization towards a holistic improvement of women's situation in Nigeria.

\section{Globalization and Feminism: Through the Eyes of Women in Africa}

Globalization is a phenomenon that has been widely researched and theorised by different scholars (mostly men) from varying and differing perspectives. The term in an encompassing sense, according to Parekh and Wilcox (2014), refers to "the economic, social, cultural, and political processes of integration that result from the expansion of transnational economic production, migration, communications, and technologies". Akanle and Taiwo (2013) went further to explain that globalization is the increasing concentration of world societies into a small "global village" where variations in the time and space and their distribution across the globe are greatly reducing. Taiwo and Shittu (2016) noted that globalization is the main instrument of hegemonic powers in the World Capitalist System used in capturing the economy and other supporting social institutions such the political and educational structures of other countries, especially, the developing nations. This situation arises as a result of the need of the Multi-National Companies located in the developed nations to take their production processes outside their home countries as a result of the increase in the average wage of workers. Thus, as they always seek for ways to maximize their profits, they encroach on other non-suspecting developing nations through the instruments of globalization such as International Organization's Structural Adjustment Programmes to establish (most times) monopolistic/oligopolistic companies that exploit both natural and human resources in these countries (Taiwo and Shittu, 2016).

Globalization, however, depends on more than the low cost of labour (mostly by women) and resources in developing countries to service the World Capitalist System. Although, it is meant to rely on the unpaid labour women render in the households, however these are hardly ever visible in the Nigerian society for the world to see and appreciate hence they are neither valued nor advertised globally, as is the case of the activities carried out by the male folks. In the same vein, the average female/woman who decides not to perform impressively at the domestic sphere in the Nigerian society is frowned at and considered "uncultured", "unhomely" and "unmarriageble". However, conformity to perform at the domestic sphere arena does not translate to her visibility in the World Capitalist System or the globe. Furthermore roles performed by the women folks as evident in domestic and care roles will contribute to 10 to 39 percent of a country's gross domestic product (GDP) if assigned monetary values according to Budlendar (2009). However, this is hardly ever the case and may never be for a very long time in the Nigerian society because it involves the disadvantaged folks (women) and not the men. This to a large extent undermines the value of women's activities in most underdeveloped and patriarchal societies like Nigeria and the implication it has for women's global advantage.

Al-Rodhan and Stoudmann's (2006) definition of globalization as "a process that encompasses the causes, course, and consequences of transnational and transcultural integration of human and non-human activities" is apt to the discussion on globalization's implications on gender relations. The consequences of the so-called integration of nations and cultures go beyond the unequal power relations and socio-economic and political dependence that exist among the Core, Semi-Periphery and Periphery countries (Taiwo and Shittu, 2016) to include deeper and foundational power relations that exist between male and female gender in different cultures especially those of the developing nations. This is why Anderson (2001) believed that gender is not only defined as distinctions of socially created and learned roles with specifications as to the physical, ideal, mental, emotional and behavioural attributes of males and females, he went further to argue that gender involves the perception and observation of "how social norms and power structures impact on the lives and opportunities available to different groups of men and women".

Unfortunately, the implications of the gendered processes of globalization and the underlying power relations between men and women are mostly ignored with the prevailing view that globalization is gender-neutral in its causes, effects, and consequences (Phalane, 2004). However, Acker (2004) argued that the subordination of women in global and capitalistic production processes started from the separation of productive labour and reproductive. The views of Marx and Engels (1956) that capitalism brought about patriarchy and the suppression of women to the private sphere of social organization is not farfetched from those of Ngwainmbi, (2011). Thus, the underdevelopment of women arises from the perception of the female gender as being inferior, less productive and unimportant. Interestingly, it is quite the opposite that the effective functioning of globalization and the World Capitalist System itself is based on the assumption of a "free labour" provided by women in households, agriculture and sometimes at work (Acker, 2004). This means that even though there will not be a reproduction without 
production, the reverse is also very true since societies will not be able to survive without the reproductive functions of women.

In order to suppress the women and uphold the mental, social and physical power of men, patriarchy as a means of social subordination and organization was entrenched in Africa right from inception. This power structure and relations is however strengthened and made worse (at the detriment of women) with the capitalist tendency to separate productive processes from reproductive roles and aggravated by globalization. Women in Africa are therefore put in positions where they constantly experience untold hardship, mental repression and loss of self and social identity as a result of the marginalization and confinement to their households. They are undervalued at home and at work place. Ironically, their unrecognized and non-remunerated functions are actually the fuel that keeps capitalism and globalization going.

The experience of sexual exploitation and harassment by African women experience in the hands of men (foreign and local alike) through forced prostitution, child trafficking and women/child labour (Jerome and Owumi, 2007, Akanle and Taiwo, 2013). Women are not only perceived as sex objects meant to satisfy the sexual urge of men in African by the men themselves but also socialized to accept that their success in the African society is dependent on their approval by the society which is "a man's world". Those prostitution which is an act performed by both male and female gender is perceived as a "feminized crime and illegality", whereas the men who perpetuate the act by paying, begging and approving of it as perceived as "sexually active", a perception that depicts the ideology of "manliness". Migrating businessmen are popularly known for their sexual promiscuity and exploitation of women in their places of destination in order to "replenish their system" and make themselves ready for the business engagements. Every year, thousands of women and children are trafficked out of Africa to European nations in order to service the sexual needs of the capitalist men in these countries (International Organization for Migration, 2008; UNICEF, 2006; UNESCO, 2007). Furthermore the derogatory reputation of women is aggravated by globalization through the internet where women's nude pictures and faces are more exposed than those of men (whose body parts are more exposed rather than their faces, except in cases where the men consent to it as part of their profession to attract more remuneration). Sexual pornography have also being utilized as means of blackmailing and destroying the reputation of women through the internet. It is also worthy of note that most poor women (and most times their female children) in Africa work as housemaids and servants in the houses of the high-class capitalists who require their services in order to function effectively at their workplace and also keep their home intact (Jerome and Owumi, 2007; Oludayo and Aderinto, 2011). Most of these jobs do not only attract very low income but are sometimes not paid direct to the females who carry out the jobs but to agents who enrich themselves exploiting the women who do the menial and stressful jobs.

These issues have made socialist feminists to argue that social constructions such class stratifications, race and gender are products of "global capitalist economic system" and reflective of the slave trade period of human history (Ngwainmbi, 2011; Acker, 2004). In recognition of the importance of women to the development of African Societies and in line with the feminist movement, this section closes with the classical statement of Anna Julia Cooper (Ngwainmbi, 2011) on the most important principle of social organization: "This law holds true in Sociology as in the world of matter, that equilibrium, not repression among conflicting forces is the condition of natural harmony, of permanent progress, and of universal freedom” (Cooper 1969).

\section{Consequences of Globalization on Women's Lives and Opportunities in Nigeria}

Nigeria used to be a flourishing agricultural-based economy (with more women than men) with strong export base in produce like cocoa, palm nuts, palm oil and groundnuts. Even with the problems of colonization and the turmoil of internal democracy experienced in the country, Nigeria continued to enjoy a degree of hegemony over other African nations in terms of agricultural production and until the discovery of oil in the 20th century (Akpan, 2012; Yusuf, 2014; Lawal, 2011). This discovery changed the whole fabric and overarching social, economic and political structures of the Nigerian society. The influx of Multi-National Corporations into the country to explore crude oil and the consequent high rate of men leaving the agricultural sector (including geographical migration to urban centres) into the exploration, industrial and manufacturing sectors further increased the load of and created new social problems for the women - especially those in rural areas (Akpan, 2012; Yusuf, 2014). Women were left with the sole burden of providing for the family (which is usually a large one as a result of men's patriarchal interests) and this they do through their underpaid and undervalued activities in the neglected agricultural sector. This situation became further aggravated with the implementation of the Structural Adjustment Programme in the mid 1980s ushered in by the International Organizations who also serve as the main agents of globalization (Shittu and Taiwo, 2016). This programme saw to the mass retrenchment of civil servants, drastic reduction of government's public and social services, deregulation of the economy (including the oil sector), opening up of the economy for foreign investments and the deregulation of the naira among others (National Centre for Economic Management and Administration, 2004). Even though some scholars have emphasized the good-meaning nature and positive aspects of Structural Adjustment Programme in the country, it is still an empirically attested fact that the programme brought more harm than good to the country in terms of consequences (Ogbimi, 2001; Shittu and 
Taiwo, 2016; Ukah, 2014; Tsikata, 1995). This in fact has been said to be the starting point of the incessant unemployment tragedy that has continued to plague the nation for decades (Nwagbara, 2001). The rendering of men (civil servants) jobless did not, however, lead to the expected result of entrepreneurship development and private sector expansion.

These men became reluctant to go back into farming which requires extensive activity and sometimes period sales before making money. They were used to the daily and monthly wages they get from the government and some other private organizations. Thus, they compete en masse for non-existing jobs with very low wages. This makes the women not only to be saddled with the responsibility of looking after themselves and children alone with very menial and low paying jobs, but also the unemployed husbands who refused to go into farming and still enforce their patriarchal authority as the head of homes. The refusal of these men to take up jobs with low wages and leaving such for struggling women in the light of the exploitative nature of Multi-National Corporations to invest in countries where they can get cheap labour in order to maximize their profits regardless of the gender or their conditions of living, further created more complications and led to more subjugation of women in Nigeria (Tsikata, 1995).

From then onwards, the plight of women (most especially the low class women) has to a large extent become worsened with increasing level and influence of globalization, World Capitalist System and neo-colonization in Nigeria. Several empirical studies have been carried out to research the consequences of globalization on women and their political and socio-economic situations in Developing countries including Nigeria (Bacchus, 2005; Tsikata, 1995). These consequences (though not mutually exclusive) range from impoverishment of women to the denial of basic economic, social and cultural rights of women as discussed below.

Women's opportunities to progress in their career pursuit are limited not only because of their reproductive and domestic responsibilities, but also because o the patriarchal interest vested on them by the men and aggravated by the women themselves and globalization. The visibility of women is an indicator of her career progress, travelling and exposure and some of these may not be possible until her children are grown up enough to take care of themselves even when there are helpers or nannies to assist. The care is not so for the male-folks. Women also have limited opportunities to participate in politics which can also make them not only recognized and able to compete in the power relations due to material/financial constraints and the ideology that women are meant to be at the background (Olurode, 2013). Those who manage to surmount these constraint and continue to contest for power still face several criticisms, violent attack and disapproval from the society for a very long time in addition to lack of funds and moral support. Many women who are allowed to participate in elections are utilized for campaigns and dumped after party victories (Oloyede, 2009). Furthermore, although the orientation about the girlchild education is on the increase, many young girls are still socialized and encouraged to pursue less prestigious and less-paying career such as secretariat studies, nursing, teaching and clerical jobs that will subjugate them under the men, while the male folks are encouraged to read more prestigious and paying jobs such as medicine, engineering, law etc. These do not only cause the women to remain more marginalized, but reduces their opportunities of becoming more visible and developed financially, emotionally, materially and otherwise.

\section{Feminization of Poverty, Unpaid and Underpaid Labour}

Even though theoretical, the concept of feminization of poverty is a reality majority of the women in Africa, and most especially Nigeria, have to face (OECD, 2010; Moghadam, 1999; Bacchus, 2005, Oludayo and Aderinto, 2011). According to Ejumudo (2013), women account for an alarming percentage of $65 \%$ of the $70 \%$ of Nigerian population living below the poverty line. He further revealed that women's income and purchasing power is approximated to be 1.495 US dollars compared to 614 US dollars for men. These figures attest to the fact that poverty in Nigeria is now arguably seen as synonymous to the female, only made worse with the current economic recession that weighed down the country's economy.

However, the high rate of poverty among women in Nigeria cannot be discussed outside the unpaid and underpaid labour they render even though International Organizations have continued to ignore this connection in order to protect their capitalist interests (Bacchus, 2005, Olutayo, 2005). Taiwo and Shittu (2016) noted that it is in the world capitalists' interest to ensure the continuous subjugation of the developing countries (including their citizens) in order to ensure the maximization of surplus value which they redirect back to their home countries. Thus, apart from the cheap natural resources they get from countries like Nigeria, they also exploit the deplorable conditions of most citizens in these countries. As a result of the "poverty-stricken conditions" of the inhabitants of developing countries including Nigeria, most Multi-National Corporations intentionally bring down the labour wages of the workers in order to perpetuate the gap between the amount of wages earned by developing countries and developed countries (Bacchus, 2005). This situation only gets worsened as developing nations now compete with one-another over which country has the lowest wage in order to attract these Transnational Companies so as to meet the so-called development criteria of International Organizations (Bacchus, 2005). This is not to talk of the gender discrimination and sexual harassment they experience from employers when they apply for or get these jobs. 
Unfortunately, women bear the major brunt of this situation as they are mostly without support of the men who refuse to engage in low-wage work or spend money recklessly without supporting their families (Ward, 1990; Elson, 1992; Bacchus, 2005). Women would therefore engage in whatever job they find whether agricultural, industrial or service oriented and regardless of the pay and stress involved in order to make a living and support their family. This is true to the extent that researchers have established that women (especially singleparent/female-headed households families) spend most of their earnings on home-related expenses and sometimes go further to include the school fees, training fees and general upkeep of the children (Donkoh, Alhassan and Nkegbe, 2014; Floro and Seguino, 2002; OECD, 2010; Taiwo, 2014, UNICEF, 2007 Yosof, 2010).

Interestingly, their coverage of household expenses does not include the unpaid labour they engage in at home. Traditionally in Nigeria and most African countries, women are regarded as the custodian of home, guardian of children and "maids" or helpers of husbands (OECD, 2010; Ferrant, Pesando and Nowacka, 2014). They are the first to wake up every morning and the last to sleep late in the night. They are required to wake up very early to clean, cook, wash, and make everyone else ready for their outing before getting themselves prepared for work and will also go through the same process at night. This is done most times without the support of the husband who sometimes batter them for "insubordination" or "neglect of their duties". Some husbands even go as far as seizing the daily/monthly wages of these women while they exhaust it on their selfish and personal matter expenditures. The social control structures such as Police do not also help matters as they most times dismiss issues of domestic violence and when entertained, find fault with the women and not the man (Immigration and Refugee Board of Canada, 2014; Oluremi, 2015). Hence, most lower-class women in developing countries like Nigeria live in a state of fear, agony and continued repression at workplace and in their households (Bazza, 2009). It is therefore a selfevident fact that there is a connection between the economic exploitation of women and the high rate of poverty manifesting in a country like Nigeria.

\section{Unequal Career Pursuit}

Propagating Westernization, globalization - through colonialism and neo-colonialism - has ensured that the social institutions of the Developing Nations, Nigeria included, are patterned and developed to look similar to that of the Western Countries. The cultural, religious, educational, familial, political and economic institutions therefore do not reflect the traditional norms and values of the people but that of foreign ideals. This process led to the entrenchment of capitalism and industrialization as the major mode of production of Nigeria and other African countries. Thus, the Nigerian society experienced a massive movement of able-bodied men from the agricultural sectors and rural areas to the urban centres in search of "greener pastures" and factory jobs (Pam, 2014; Lawal and Okeowo, 2014). Women in rural areas were therefore left to till the soil and sell agricultural produce in major markets so as to survive.

In the urban centres, where most educational institutions are located, more male children were sent to schools because of the belief that they will bring back fortune to the family when they get the "white man's job". The females were greatly discriminated against in terms of education as they were believed to always end up "in another man's kitchen"- - hence, not bringing any foreseen economic benefit to the family of orientation. Therefore, for a very long time, only male children had access to good and higher education which provided them career opportunities like medical doctors, human resource managers, lawyers, pilots and other highly valued jobs. Where women were given education, they were limited to primary schools, secondary schools or at most colleges of education and thus were only opened to such jobs as teachers, secretaries, nurses, cleaners and other "care-giving" economic roles (Obi, 2009; Omoreigie and Abraham, 2009; Okpukpara and Chukwuone, 2005).

The manifestation of this belief in social relationships and differing career roles of males and females started from the family socialization process of female and male children. The female child is taught to take care of the home and take up household responsibilities such as cooking, cleaning, looking after others, fetching water, and washing among others. On the other hand, the male child is given few household responsibilities and therefore has more time to focus on education while also encouraged to develop innovative and entrepreneurship skills. These factors make the female child (especially those in rural areas) not to perform well enough in schools and therefore more likely to drop out at the early stage of her academic career. The male child, however, is able to put his energy into getting good grades in school as the female looks after him at home and as a result will have access to higher levels of education which then translates to well-paid jobs and higher economic positions (Gender in Nigeria Report 2012, pp. 25-35).

Another major setback to women's career pursuit is the reproductive roles women play in the society. Due to the societal expectation and high social value attached to marriage, family and childbirth, women have to therefore consider either staying at home as full housewives or take up low status jobs in order to keep the family intact and look after the children while men have freedom in choosing any career path they want with little regard to their family's situation. In fact, most times when men get jobs that require them to relocate, the wives and entire family have no choice but to move with them to the new location regardless of whatever job the wives were doing at the old location. This is not possible the other way round as women are meant to stay close to their homes and create 
more time (at the detriment of their jobs) for the husband and children. These not only make them stationary but also to a great extent limit their career opportunities as they end up taking jobs that are underpaid and with few working hours in order to be able to get back home in time to carry out the house chores (Gender in Nigeria Report 2012, pp. 17-23).

In cases where women are bent on fully pursing their career interests, they are most times put in precarious situations where they have to choose between their jobs or family and the choice of job over family usually end up in divorce or single-parenthood. However, women are meant to endure the marriage even when men disregard them make their jobs the paramount choice of the two. Even when the husband permits the wife to work longer hours, he would be "compensated" for such considerations with the relinquishment of the wife's wages and provision must be made for female house-helps which sometimes end in infidelity on the part of the man.

\section{Patriarchy and Unequal Power Relations}

Nigeria, and most other African countries, is traditionally a patriarchal society with forms of social organization that ensure the male becomes head of the family and socio-economic titles are traced through the male line. Therefore, right from time, traditional societies in Nigeria have promoted male dominance in terms of power relations - in family, political, educational, economic and religious institutions. Women have been socialized to be second fiddle to men when it comes to decision making in all levels of the society even on matters that mostly concern them.

This situation has been said to arise from the confinement of women to the private sphere of the society while men dominate the public sphere which includes politics, religious and economy. Of course, power resides in the public sphere and the confinement of women to the private sphere only leads to further subjugation and power dependency. Despite the cliché, it is empirically evident that "he, who pays the piper, dictates the tune". In all societies of the world, those who control the means of production, the source of beliefs, and the making of policies determine the relations of production and thus own the socio-political power in the society. This is as true everywhere as it is in Nigeria where men dominate these various aspects of the society (Gender in Nigeria Report 2012, pp. 53-58). This case can be exemplified with the traditional Yoruba's society's power relationship where the man (okunrin) controls the hoe (oko - the instrument of production) and the land (oko - the means of production) and therefore becomes the head of the family (oko - the owner of means of production). At the level of households, since women are mostly confined to homes and are not financially independent, they have to suppress their individuality and freedom in order to be in the good graces of their husbands.

Even in situations where women take up social positions imbued with power, they are limited in terms of how far they can wield such power and they can experience discrimination or sexual harassment from men below and above them in position. Therefore, despite the feminist movement and cry for gender equality that came alongside globalization which make women to be aware of their plight and the need to rise up against oppression, the situation is worse today than ever as men (especially those in power) now become more resistant than ever to women liberation and thus bring up several obstacles to prevent their rise to power or control of resources. Such obstacles in Nigeria include increased financial demands to acquire the forms for political aspiration, sexual harassment, blackmail, empowering other women in the form of giving bribes and gifts to antagonize the female political aspirants through campaigns, voting against them and general unsupportive comments against the "woman who has supposed refused to realise that her place is supposed to be in the kitchen at the background". Recently, most Nigerians laugh over the comment of the Nigerian president about his wife (the first lady) when he said that his wife's place is in the kitchen and belongs to the "other room" established purposely to take care of him. These again point attention to the fact that women are not only seen as care-givers, but are also perceived as sex object. Again while the position of the first lady is so because of the husband's role as president, she is still relegated to the background by her own husband through the comment he makes. This further predicts the unlikelihood for a female presidential aspirant (like Hilary Clinton in America) to come out in Nigeria even in the next decade as both males and female antagonist will be out to shut her down.

\section{Loss of Identity}

This is another factor militating against the emancipation of women in spite of the benefits of globalization. Globalization emphasizes visibility irrespective of time, distance and space. Such visibility overtime is not unconnected with consistence in identity. Women through marriage, a value that is high celebrated and held in high esteem in African society and Nigeria in particular, loss their identity. A women's surname i.e maiden name is changed completely as soon as she gets married and this is usually publicised through the mass media. Women who struggle in the midst of the challenges and hassles indirectly ascribe the glory to their husbands through their new names (Taiwo and Akanle, 2013). For instance women in the academia are usually called by their supposed surname which is that of their husbands. A woman's identity overtime becomes difficult to be traced to her on father except in cases where conscious efforts are made to do so. Women who insist on doing so are sometimes frowned through religious doctrines and moral tenets that she is not "cleaving to her husband as one", except she 
gets approval from her husband to include her maiden name in her identity. Again, the need to continue the name/lineage and retain the "identity" of the family through the males in a patriarchal society like Nigeria, gives rises to the emphasises on male preference or son preference so that women who are married into their homes and unable to give birth to a male child (a sex usually determined by the chromosome released by the husband), are afraid of losing their husbands to another wife (except for families that are sensitive to the female folk or less patriarchal). Some women are ready to risk their lives and continue to get pregnant in order to have a male child or children for their husbands as they are usually blamed for the inability to do so. The woman is also usually blamed for infertility or inability to give birth to children for the man and may be expected to remain faithful to the man in the marriage and be childless while the man may be justified if he gets a child outside marriage. This account for why women in the Eastern part of Nigeria who were not able to give birth or did have male children, marry wives for their husband's to help them do so in order to continue the lineage which to a large extent is also highly connected to retaining the identity of the man.

Fixed assets such as landed properties, buildings and estates in most culture are bequeathed to the male children and not the females because of the belief that they will get married and not continue the family name or identity since they are expected to lose it to their husband's for like. Some culture that manage to do otherwise like the Yakurr people, usually bequeath moveable inheritance their female children. These further under develops the women as fixed properties such as lands, houses, properties owned by the male folks are advertise and posted on the internet as endowment of the male folks.

Furthermore, the practice of widow inheritance in some cultural settings in the Eastern parts of Nigeria does not only limit the freedom of the women and limit her life chances and opportunities, but also debars her from taking decisions about what identity she wants to retain or change to. Most men in these communities sexually exploit and maltreat widows and their offspring who vehement refused to be humiliated and treated like "properties" that are transferable from one hand to another. Suffice it to say that the term "property" is also used to refer to women who are married into most homes in the Eastern Nigeria. So that even when men from these parts of the world brag that they take care of their wives, they refer to them as their "properties or investment" and expect that their wives serve as basis upon which they can be economically assessed. In addition, harmful cultural practices such as female genital mutilation (FGM) and early girl-child marriage are still been practiced and have further aggravated the adverse effects on women in the Nigerian society. Some women as a result of these practices end up becoming a shadow of themselves, while some are still struggling to live a normal life.

\section{Refocusing the Debate: Empowering the Disadvantaged through Globalization}

The underdevelopment of women in Nigeria is not just limited to an aspect of the society alone. It is manifested in all social institutions and groups and the social relations that occur within them. Therefore, any attempt to correct this situation must be holistic in its approach and encompassing in its reach. This means that there must be conscious efforts on the part of everybody - men and women included - to bring about a positive change in the political and socio-economic conditions of women in Nigeria. This redirection is important not only for the emancipation of women but also for the furtherance of Nigeria's effort in achieving sustainable development. There is no doubt that the development of women is very important in the overall development of any country. They are the custodian of norms and values, driver of grassroots development and promoter of societal unity through socialization. In Nigeria, women are the major stakeholders in Agriculture, and any serious attempt by the country to revive its agricultural base and service its degenerating industrial sector while reducing overdependency on importation and its depleting oil resources must take them into consideration (UNICEF, 2007; Gender in Nigeria Report, 2012; World Economic Forum, 2013).

This means all stakeholders must intensify their efforts in ameliorating the socio-economic conditions and enhancing the political status of women through the provision of an equitable platform for accessing socioeconomic resources and political power. There is therefore the need to refocus the debate on the underdevelopment of women towards their empowerment through by channelling the impact of globalization in the country in a more positive direction.

To start with, there is a need for the government to revisit its policies as they relate to gender composition of civil/public service and ministerial positions in the country. Efforts should be made by the government to remove the glass ceiling limiting the career growth of women in Military and some governmental parastatals. The Nigerian government must look further into developing policies that provide for the adequate representation of women in decision-making roles and top positions in educational, economic and political institutions. Beyond this however, the government must ensure that the negative effects of globalization and importation are prevented through the development and implementation of policies that provide for and promote the improvement of agricultural practices and technologies by the rural women. Nigeria needs to look inwards to the mechanization of agriculture and sales promotion of agricultural produce as against imported food items. This can be done through soft loan provision and intensified agricultural extension services in agriculturally dependent communities in Nigeria.

Since most Nigerian government policies are transient and heavily dependent on the personalities and party 
in government, a more lasting instrument needs to be put in place in terms of new legislative bills that will ensure the protection of women against discrimination in workplace and other socio-political arrangements. Also, there should be enforcement of laws that proscribe the battering and maltreatment of women in their domestic homes as well as uphold their individuality and ability to make informed decisions concerning their career, income and relationship life. Appropriates bills should be passed into laws to completely eradicate harmful and dehumanizing cultural practices affecting women such as female genital mutilation, widow inheritance and early girl-child marriages.

Good education is highly valued in Nigeria today and ensuring women get high degree education is a means of empowering them for personal and social development. Education is not an exclusive right of any single individual or gender. There should be serious implementation of policies that promote compulsory education of female Nigerian children up to the secondary level and special provisions should be made in terms of scholarships and sponsorships for female children to further their education to the tertiary level especially those from low class families and rural areas. This will not only help in adequately utilizing their talents and abilities for all-round sustain development but also bring about promotion of gender rights and avenue for the contribution of women to the issue of national development.

Even though institutional approaches are important in bringing about improvement in gender relations and globalization's implications on women in Nigeria, the need to re-orientate the individuals from the household level to the highest level of public institutions. This can be done through various public programmes organized at local levels and communities that sensitize people on the need for equal gender relations and the ways this can be achieved. The media (television, radio, newspapers) and social media platforms are also strategic ways information on gender equality can be passed across to the people. The government can also bring up nation-wide initiatives and action programmes to galvanize such as the "Change Begins with Me" initiative of the present government.

Most important, however, is the economic empowerment of women in Nigeria especially those in the rural areas in order to improve their standard of living. Thus, programmes that will help them improve their agricultural practices, production and output sales will be a welcome development. Also in this aspect is the promotion of entrepreneurship development among women in the country through provision of avenues that encourage women to bring up business ideas, and provision of funds to enable them kick-start their enterprises.

\section{Conclusion}

This paper has attempted an expository analysis and discussion of how the traditional norms and values in Nigeria and the consequences of globalization interact to subjugate women in the country; thus, furthering their underdevelopment. The paper argued that although globalization has contributed positively to the gender equality movement in developing countries and Nigeria especially with some recorded developments, gender relations and access to socio-economic and political resources still remain largely unequal with the consequences of globalization compounding the situation. Furthermore, the paper examined the disadvantages of globalization on the development of women in Nigeria through the lens of gender inequalities issues such as: feminization of poverty, underpayment of female workers and the unpaid labour they render at homes; unequal career pursuit among the men and women; patriarchy and unequal power relations that exist in Nigeria's traditional settings; and the loss of identity and individuality that women experience in their relationship with men.

With emphasis on the importance of women's personal, socio-economic and political development in charting a sustainable development trajectory for the nation, attempt was made to provide a holistic framework for the empowerment of women through the instruments of globalization. These areas include the inclusion of women in political activities and decision making, the implementation of policies that border on equal rights and access to resources in education, economy and politics and agricultural development. Others are promulgation of laws proscribing domestic violence, reorientation of all citizens through organization of sensitizations programmes and nation-wide initiatives. The paper however emphasized the role of economic empowerment of and entrepreneurship development among women as the most significant aspect of any sustainable development programme by the Nigerian government.

With this redirection of focus and sustainable development efforts, it is believed that Nigeria (and Africa as a continent) will be a land of equal opportunities where individual dreams and goals will be achievable and women will fully, adequately and efficiently play their part in charting the course of a sustainable development for the country.

\section{REFERENCES}

Acker, Joan. 2004. Gender, Capitalism and Globalization. Critical Sociology. Vol. 30, No. 1, pp. 17-41. Accessed from faculty.maxwell.syr.edu/mdevault/Critical\%20Soc.Nov.03.pdf on 21st October, 2016

Anderson, M. 2001 "Shifting the Centre and Reconstructing Knowledge". (Eds). Anderson, M.I. and Collins, P.H. Race, Class and Gender, An Anthology Fourth Edition . Wadsworth. U.S.A. Thomas Learning Publisher. $40-48$ 
Akanle, O. and Olutayo, A.O. 2010 "Globalization and Development Nexus: Nigeria Entangled. Mambayya House Journal of Democratic Studies. Vol 2. 18-39

Akanle, O. and Taiwo, P. 2013 "Globalization and Inequality" (Eds) Aborisade, R. Omobowale, A. Akanle, O. Essentials of Sociology. Ibadan University Press 283-320

Akanle O. 2011. "The Sociology of Gender Equality and Development in Democratizing Nigeria". The Nigerian Journal of Sociology and Anthropology. Vol. 9. 22-36

Akpan, N. S. 2012. From Agriculture to Petroleum Oil Production: What has changed about Nigeria's Rural Development? International Journal of Developing Societies. Vol. 1, No. 3, 97-106. Accessed on 21st October, 2016 from http://www.worldscholars.org/index.php/ijds/article/download/154/95

Al-Rodhan N. R. F and Stoudmann G. 2006. Definitions of Globalization: A Comprehensive Overview and a Proposed Definition. Program on the Geopolitical Implications of Globalization and Transnational Security. Geneva Centre for Security Policy.

Bacchus, Nazreen. 2005. The Effect of Globalization on Women in Developing Nations. Honors College Theses. Pforzheimer Honors College, Pace University. Accessed 7th October, 2016 from http://digitalcommons.pace.edu/honorscollege_theses/2

Bazza, H. I. 2009. Domestic Violence and Women's Rights in Nigeria. Societies Without Borders. No. 4, pp. $175-$ 192.

Berg, Claes. 2011. The Global Financial Crisis and the Great Recession: Causes, Effects, Measures and Consequences for Economic Analysis and Policy. Being a paper presented at a workshop on Monetary Policy, Macroprudential Policy and Fiscal policy at the Centre for Central Banking Studies of Bank of England from 17th May to 19th May, 2011. Retrieved on 20th October, 2016 from www.bankofengland.co.uk/research/documents/ccbs/cbs_cew2011/paper_berg.pdf

BRIDGE. 2001. Feminisation of Poverty. Institute of Development Studies. A briefing paper for the Swedish International Development Cooperation Agency (SIDA). Retrieved from http://www.bridge.ids.ac.uk/sites/bridge.ids.ac.uk/files/reports/femofpov.pdf on 20th October, 2016.

Budlender, D. 2008 "The Statistical Evidence on Care and Non-care Work across Six Countries. Paper 4." Gender and Development Programme United Nations Research Institute for Social Development, Geneva

Cooper, Anna Julia. 1969. A Voice from the South by a Black Woman from the South. New: Negro University Press. Cited in Ngwainmbi, J. M. 2011. Globalization, Globalization of Feminism and the Liberation of Women: The Case of African Women. International Journal of Business and Social Science. Vol. 1, No. 24, pp. $35-50$

Donkoh, S. A., Alhassan, H., and Nkegbe, P. K. 2014. Food Expenditure and Household Welfare in Ghana. African Journal of Food Science. Vol. 8, No. 3, pp. 164-173.

Ejumudo, K. B. O. 2013. Gender Equality and Women Empowerment in Nigeria: The Desirability and Inevitability of a Pragmatic Approach. Developing Country Studies. Vol. 3, No. 4, pp. 59-66

Elson, Diane. 1992. From Survival Strategies to Transformation Strategies: Women's Needs and Structural Adjustments. Unequal Burden: Economic Crises, Persistent Poverty and Women's Work. Cited in Bacchus, Nazreen. 2005. The Effect of Globalization on Women in Developing Nations. Honors College Theses. Pforzheimer Honors College, Pace University. Accessed 7th October, 2016 from http://digitalcommons.pace.edu/honorscollege theses/2

Erinosho, O., 2005. "The Burden of Our Women" The 29 $9^{\text {th }}$ Interdisciplinary Discourse Organized by the Post Graduate School, University of Ibadan, Nigeria.

Ferrant, G., Pesando, M. L. and Nowacka, K. 2014. Unpaid Care Work: The missing link in the Analysis of Gender gaps in Labour Outcomes. OECD Development Centre, Paris.

Floro, M. S. and Seguino, S. 2002. Gender Effects on Aggregate Saving: A Theoretical and Empirical Analysis. Policy Research Report on Gender and Development. Working Paper Series No. 23. Retrieved from http://www.worldbank.org/gender/prr on 21st October, 2016.

Gender in Nigeria Report 2012: Improving the Lives of Girls and Women in Nigeria. British Council Nigeria. 2nd Edition.

Haug, W. F. 2007. Contradictions of Globalization. An inauguration lecture at the Great Philosophical Event in Tampere Hall, Finland in March, 2007. Accessed on 20th October, 2016 from http://www.wolfgangfritzhaug.inkrit.de/documents/Contradictions-of-Globalization-07.pdf

Immigration and Refugee Board of Canada (IRB). 2014. Nigeria: Domestic Violence, including Lagos State; legislation, recourse, state protection and services available to victims (2011-October 2014) [NGA104980.E] Accessed on 21st October, 2016 from http://www.ecoi.net/local_link/291839/412404_en.html

International Organization for Migration. 2008. Human Trafficking in Eastern Africa: Research Assessment and Baseline Information in Tanzania, Kenya, Uganda, and Burundi. IOM, Switzerland. pp. 5.

Owumi B. and Jerome P. 2007 "Changing Family Structures/ Values and the Incidence of Human Trafficking in Edo State In The Nigerian Journal of Sociology and Anthropology Vol. 5, 
Lawal, A. S. and Okeowo, T. A.. 2014. Effects of Rural Urban Migration on Labour Supply in Cocoa Production in Ondo East Local Government Area of Ondo State. International Letter of Natural Sciences. Vol. 18, pp. $1-11$.

Lawal, W. A. 2011. An Analysis of Government Spending on Agricultural Sector and its Contribution to GDP in Nigeria. International Journal of Business and Social Science. Vol. 2, No. 20, pp. 244-250. Accessed on $21 \mathrm{st}$ October, 2016 from http://www.ijbssnet.com/journals/Vol_2_No_20_November_2011/26.pdf

Marx, Karl and Engels, Friedrich. 1956. The Holy Family. Moscow: Foreign Language Pushing House. Cited in Ngwainmbi, J. M. 2011. Globalization, Globalization of Feminism and the Liberation of Women: The Case of African Women. International Journal of Business and Social Science. Vol. 1, No. 24, pp. 35-50

Moghadam, V. M. 1999. Gender and Globalization: Female Labor and Women's Mobilization. Journal of World Systems Research. 2: 367-388. Cited in Bacchus, Nazreen. 2005. The Effect of Globalization on Women in Developing Nations. Honors College Theses. Pforzheimer Honors College, Pace University. Accessed 7th October, 2016 from http://digitalcommons.pace.edu/honorscollege theses/2

Moghadam, V. M. 2005. The 'Feminization of Poverty' and Women's Human Rights. SHS Papers in Women's Studies/Gender Research. No. 2. Accessed on 20th October, 2016 from http://www.cpahq.org/cpahq/cpadocs/Feminization of Poverty.pdf

National Centre for Economic Management and Administration. 2004. Understanding Structural Adjustment Programme in Nigeria. A draft report submitted to Global Development Network and presented at the Workshop on Understanding Reform, New Delhi, India. Retrieved on 21st October, 2016 from http://www.gdn.int/html.GDN_funded_papers.php?mode=download\&file=Nigeria-first-draft_176.pdf

Ngwainmbi, J. M. 2011. Globalization, Globalization of Feminism and the Liberation of Women: The Case of African Women. International Journal of Business and Social Science. Vol. 1, No. 24, pp. 35-50

Nwagbara, E. N. 2001. The Story of Structural Adjustment Programme in Nigeria from the perspective of the Organized Labour. Australian Journal of Business and Management Research. Vol. 1, No. 7, pp. 30-41.

Obi, C. C. 2009. Gender Differences in Educational Opportunities: The case of Girl-Child Education in Nigeria. African Economic and Business Review. Vol. 7, No. 2, pp. 1-12.

OECD. 2010. Gender Brief. OECD, Paris. pp. 8-17.

Ogbimi, F. E. 2001. Structural Adjustment is the Wrong Policy. African Technology Forum. Vol. 8, No. 1. Accessed on web.mit.edu/africantech/www/articles/PlanningAdjust.htm on 21st October, 2016.

Okpukpara, B. C., and Chukwuone, N. A. 2005. Child Schooling in Nigeria: The Role of Gender in Urban, Rural, North and South Nigeria. Retrieved on 21st October, 2016 from www.saga.cornell/edu/saga/educconf/okpukpara.pdf

Oludayo, T. and Aderinto, A., (2011) "Socio-demographic Predictors of Domestic Outsourcing among Working women in Ibadan" Pakintan Journal of Social Sciences Vol 8. No. 4 198-204

Olutayo, A. 2005. Women in Informal Long Distance Trade: The Family and the Rural-Urban Market Nexus in Southwestern Nigeria. Ibadan Journal of the Social Sciences. Vol . 3. No. 2

Oluremi, F. D. 2015. Domestic Violence against Women in Nigeria. European Journal of Psychological Research. Vol. 2, No. 1, pp. 24-33.

Olurode, L. 2013. State and Political Participation: Women in Nigeria's 2011 Elections. Discussion Paper No. 4, April 2013. Friedrich Ebert Stifung

Oloyede, I. 2009. Women: The Neglected Force in Public Administration. Paper presented at $41^{\text {st }}$ Inaugural Lecture- Lagos State University, Ojo-Lagos

Omoreigie, N. and Abraham, I. O. 2009. Persistent Gender Inequality in Nigerian Education. https://nau.edu/uploadedFiles/Academic/COE/About/Projects/Persistent $\% 20$ Gender\%20Inequality\%20in\% 20Nigerian\%20Education.pdf. Accessed on 21st October, 2016.

Pam, Y. D. 2014. Rural-Urban Migration among Youths in Nigeria: The Impacts on Agriculture and Rural Development. IOSR Journal of Humanities and Social Science. Vol. 19, Issue 3, Ver. II, pp. 120-123.

Parekh, Serena and Wilcox, Shelley, "Feminist Perspectives on Globalization", The Stanford Encyclopedia of Philosophy (Winter 2014 Edition), Edwward N. Zalta (ed.), URL = http://plato.stanford.edu/archives/win2014/entries/feminism-globalization/. Accessed 13th October, 2016.

Phalane, Manthiba. 2004. Globalisation and the Feminisation of Poverty: A South African Perspective on Expansion, Inequality and Identity Crisis. Gender, Economies and Entitlements in Africa. pp.159-166.

Sabarwal, S., Sinha, N., and Buvinic, M. 2009. The Global Financial Crisis: Assessing Vulnerability for Women and Children. World Bank Internal Policy Note. Accessed from http://www.worldbank.org/financialcrisis/pdf/Women-Children-Vulnerability-March09.pdf on 20th October, 2016.

Taiwo, P. 2014. Micro-Credits and the Health-seeking Behaviour of Women in Edo state Nigeria. An unpublished Ph.D thesis submitted to the Department of Sociology, Faculty of the University of Ibadan

Taiwo, P. 2012 “Attitude of Women Towards Family Planning in Selected Rural Communities of Ibadan” In 
African Journal for Psychological Study of Social Issues. Vol. 15, No.1 Pgs 125-208

Taiwo, P. and Owumi, B.E (2014) "Integrating Health services into Microfinance Operations for Sustainable Poverty Alleviation: The Case of Female Clients in Edo State" Ibadan Journal of the Social Science, Vol 12, No. 2

Taiwo, P. and Shittu, O. S.. 2016. World Capitalist System and Globalization: Reconsiderations for Achieving Sustainable Development in Nigeria. A paper to be presented at the Annual Conference of the Nigerian Anthropological and Sociological Practitioners Association (NASA), in November, 2016.

The Royal Institute of International Affairs. 2015. Overcoming the Risks and Contradictions of Globalization. The 2015 London Conference Background Paper. Accessed from https://www.chathamhouse.org/sites/files/chathamhouse/London $\% 20$ Conference $\% 202015 \% 20 \% 20$ Backgro und \%20Paper\%20Session\%20Two.pdf on 20th October, 2016

Tsikata, Dzodzi. 1995. Effects of Structural Adjustment on Third World Network. Global Policy Forum. Accessed on 21 st October, 2016 from https://www.globalpolicy.org/component/content/article/218/46625.htm

Ukah, Michael. 2014. Structural Adjustment Programme and its Negative Effect on Education in Nigeria: A philosophical Reconceptualization. International Journal of Public Administration and Management Research. Vol. 2, No. 2, 170-186.

UNESCO. 2007. Human Trafficking in South Africa: Root Causes and Recommendations. Policy Paper Poverty Series. UNESCO: Paris. No. 14.5 (E), pp. 7-12.

UNICEF. 2006. Trafficking in Human Beings, especially Women and Children, in Africa. Innocenti Insight. 2nd Edition. pp. 5-15.

UNICEF. 2007. Equality in the Household. The State of the World's Children. pp. 16-35.

United Nations. 2006. 2004 World Survey on the Role of Women in Development: Women and International Migration. New York: United Nations Publishing Section. Retrieved from http://www.un.org/womenwatch/daw/public/WorldSurvey2004-Women\&Migration.pdf on 20th October, 2016.

Verick, Sher and Islam, Iyanatul. 2010. The Great Recession of 2008-2009: Causes, Consequences and Policy Responses. Institute for the Study of Labour Discussion Papeer Series. Discussion Paper No. 4934. Accessed on 20th October, 2016 from http://www.southbaylawfirm.com/blog/upload/Financial-Crisis-Overview.pdf

Ward, Katharine. 1990. Women Workers and Global Restructuring. New York: Cornell University Press. (Introductory Chapter) Cited in Bacchus, Nazreen. 2005. The Effect of Globalization on Women in Developing Nations. Honors College Theses. Pforzheimer Honors College, Pace University. Accessed 7th October, 2016 from http://digitalcommons.pace.edu/honorscollege theses/2

World Economic Forum. 2013. Five Challenges, One Solution: Women. Global Agenda Council on Women's Empowerment 2011 - 2012. Retrieved on 21st October, 2016 from www3.weforum.org/docs/WEF_GAC_WomensEmpowerment_FiveChallengesOneSolution_Compendium 2013.pdf.

Yosof, A. S., and Duasa, J. J. 2010. Household Decision-Making and Expenditure Patterns of Married Men and Women in Malaysia. Journal of Family and Economic Issues. Vol. 31, No. 3, pp. 371-381.

Yusuf, S. A. 2014. Role of Agriculture in Economic Growth and Development: Nigeria Perspective. Munich Personal RePEc Archive. Paper No. 55536. Retrieved from http://mpra.ub.uni-muenchen.de/55536/ on 21st October, 2016. 